\title{
EVALUASI PENYELENGGARAAN MADRASAH ALIYAH NEGERI INSAN CENDIKIA KOTA BATAM
}

\section{EVALUATION OF IMPLEMENTATION MADRASAH ALIYAH NEGERI INSAN CENDEKIA CITY OF BATAM}

\author{
Sumarni, Opik Abdurrahman Taufik \\ Puslitbang Pendidikan Agama dan Keagamaan, Badan Litbang dan Diklat, Kementerian Agama RI \\ email: marni_ch@yahoo.com.au
}

Naskah Diterima: 13 September 2020; Direvisi: 6 Desember 2020; Disetujui: 15 Desember 2020

\begin{abstract}
This paper aims to evaluate madrasas that have been designed to have advantages in terms of input, process, output, and outcome, namely Madrasah Aliyah Negeri Insan Cendikia (MAN IC) Batam City. This research uses a qualitative approach. The research informants were the Head and Deputy Head of MAN IC Batam City, Head of Administration, teachers, students, and parents of students. The data analysis used a qualitative descriptive technique. The results showed that the implementation of MAN IC Batam City, in general, has been running by the Guidelines for Managing Cendikia Insan MAN. The recruitment process for students and teaching and education staff is carried out under established procedures. However, there are still problems, especially in the presence of educators. The status of teachers who are accepted by MAN IC is permanent teachers, not civil servants, making them take the opportunity to take the CPNS test. When accepted by civil servants they were not placed in the MAN IC Batam City. It is feared that changing teachers often will have an impact on students. Infrastructure facilities that support the teaching and learning process at a minimum have also been fulfilled. However, teacher dormitory is far from being fulfilled. The output produced by MAN IC Batam has been good, becoming the best madrasa and many achievements have been made in three years, both academic and non-academic achievements.
\end{abstract}

Keywords: Evaluation; Implementation; MAN IC

\begin{abstract}
Abstrak
Tulisan ini bertujuan untuk mengevaluasi madrasah yang sejak awal pendiriannya didesain memiliki keunggulan baik dari sisi input, proses, output maupun outcome yaitu Madrasah Aliyah Negeri Insan Cendikia (MAN IC) Kota Batam. Penelitian ini menggunakan pendekatan kualitatif. Informan penelitian adalah Kepala dan wakil kepala MAN IC Kota Batam, Kepala Tata Usaha, guru, peserta didik, dan orang tua siswa. Analisis data menggunakan teknik deskriptif kualitatif. Hasil penelitian menunjukkan bahwa penyelenggaraan MAN IC Kota Batam secara umum telah berjalan sesuai dengan Pedoman Penyelenggaraan MAN Insan Cendikia. Proses rekriutmen siswa dan tenaga pendidik dan kependidikan berjalan sesuai dengan prosedur yang ditetapkan. Namun masih ada permasalahan khususnya pada keberadaan tenaga pendidik. Status guru yang diterima MAN IC adalah guru tetap bukan PNS membuat mereka mengambil kesempatan mengikuti tes CPNS. Ketika diterima PNS mereka tidak ditempatkan di MAN IC Kota Batam. Seringnya berganti guru dikhawatirkan akan berdampak pada peserta didik. Sarana prasarana yang menunjang proses belajar mengajar secara minimal juga sudah terpenuhi. Namun untuk asrama guru masih jauh dari terpenuhi. Output yang dihasilkan MAN IC Batam sudah baik, menjadi madrasah terbaik dan banyak prestasi yang sudah diraih dalam tiga tahun baik prestasi akademik maupun non akademik.
\end{abstract}

Kata kunci: Evaluasi; Penyelenggaraan; Madrasah Aliyah Negeri Insan Cendikia 


\section{PENDAHULUAN}

Program membangun daya saing madrasah di bidang sain dimulai ketika ada kegelisahan bagaimana melahirkan generasi muda muslim yang unggul di bidang sains (Murtadlo, 2017a). Untuk memenuhi kebutuhan sumber daya manusia berkualitas tinggi dalam penguasaan Iptek yang di dasari iman dan takwa, maka Kementerian Agama melanjutkan visi dan misi BJ. Habibie dengan membuat program Madrasah Aliyah yang secara khusus berkonsentrasi menjadi terdepan di bidang sains, yaitu MAN Insan Cendekia (IC). MAN IC Batam sebagai salah satu lembaga pendidikan unggulan di Indonesia yang juga memiliki sejarah panjang dan menarik untuk dikaji lebih mendalam.

Terdapat tiga model penyelenggaraan pendidikan, yaitu model minimal pembelajaran, model pembelajaran standar dan model layanan pendidikan unggul (Murtadlo, 2017b). MAN IC termasuk model yang ketiga dalam hal ini, sehingga membutuhkan biaya yang tinggi dalam mencapai tujuan pendidikannya, biasanya bekerjasama dengan pemerintah daerah.

Sebuah madrasah dikatakan unggul apabila prestasi akademik para siswanya memang unggul dibandingkan dengan prestasi akademik madrasah-madrasah lainnya di kota yang sama, di provinsi yang sama, dan bahkan memperlihatkan prestasi nasional yang membanggakan (Rosyada, 2017) dan hal yang paling berpengaruh pada prestasi akademik madrasah unggul tersebut adalah guru (Rosyada, 2013).

Persoalan mutu madrasah masih terus menjadi perbincangan di masyarakat. Kualitas pendidikan di madrasah negeri sudah cukup baik dan dapat bersaing dengan sekolah umum negeri, bahkan beberapa lebih unggul. Namun demikian untuk madrasah yang didirikan swasta, sebagian masih tertinggal dalam mutu pendidikannya. Sementara madrasah swasta jumlahnya jauh lebih besar dibanding madrasah negeri. Data tahun 2019/2020 menunjukkan jumlah madrasah sebanyak 52.576 lembaga yang terdiri dari Madrasah Ibtidaiyah (MI) sebanyak 25.593 lembaga, Marasah Tsanawiyah (MTs) sebanyak 18.176 lembaga dan Madrasah Aliyah (MA) sebanyak 8.807 lembaga (Agama, 2019). Dari jumlah tersebut sekitar $91.74 \%$ merupakan madrasah swasta. Banyak faktor yang menyebabkan mutu madrasah terutama madrasah swasta masih rendah seperti sarana prasararana, sumber daya manusia, biaya, dan lain sebagainya.

Pada jenjang Pendidikan menengah, Kementerian Agama (Kemenag) melalui Direktorat Pendidikan Madrasah, Direktorat Jenderal Pendidikan Islam (Ditjen Pendis), sudah sejak lama membuat kebijakan-kebijakan dalam rangka meningkatkan mutu, daya saing, dan perluasan akses dalam penyelenggaraan Pendidikan. Kebijakan ini diwujudkan dengan menyelenggarakan madrasah unggulan dengan beberapa jenis seperti: 1) Madrasah Reguler; 2) Madrasah Aliyah Keagamaan (MAK) yang didirikan tahun 1993; 3) Madrasah Riset didirikan tahun 2013; 4) Madrasah Akademik dalam bentuk Madrasah Aliyah Negeri Insan Cendekia (MAN IC) didirikan tahun 2001.

Diantara beberapa bentuk penyelenggaraan madrasah unggulan tersebut, MAN IC merupakan salah satu prototype madrasah akademik, dan merupakan sebuah model satuan pendidikan madrasah berbasis asrama pada jenjang pendidikan menengah, yang memadukan kekhasan pendidikan agama Islam dengan pengayaan pada bidang ilmu pengetahuan dan teknologi. Lahirnya Madrasah Aliyah Negeri Insan Cendikia (MAN IC) di Indonesia dikarenakan masih adanya kesenjangan antara madrasah yang diidealkan masyarakat muslim dengan realitas sebagian besar madrasah yang belum memiliki keunggulan. Keunggulan artinya keadaan unggul; kecakapan, kebaikan dan sebagainya yang lebih dari pada yang lain. Madrasah memiliki keungggulan jika input-nya (siswa) potensial, proses berkualitas (tujuan, pendidik, siswa, bahan, metode/ sarana, dana, alat media dan manajemen), output-nya berkualitas (alumni) dan outcome-nya baik. Menurut Rahim, madrasah yang unggul itu harus memiliki keunggulan dalam 3 aspek, yaitu pembentukan moral/karakter, penguasaan sains dan penguasaan life skill (Taufik, 2014).

Sejak berdiri tahun 2001, MAN IC terus berkembang. Saat ini sudah ada 24 MAN IC yang tersebar di wilayah Indonesia. Kebijakan pemerintah dengan memperluas akses 
pendidikan madrasah yaitu berdirinya MAN IC di seluruh propinsi di wilayah Indonesia, di satu sisi, memberikan kesempatan yang besar pada siswa untuk belajar di MAN IC dan juga memberikan keadilan bagi seluruh wilayah Indonesia. Namun disisi lain pendirian MAN IC secara masif ini, dalam kenyataan tidak diimbangi dengan pendanaan yang mencukupi seperti pada awal-awal pendiriannya dulu. Keterbatasan anggaran menjadi alasan Kemenag pusat, sehingga penyelenggaraan MAN IC saat ini banyak menuai berbagai persoalan, dan yang paling nyata dirasakan adalah dicabutnya subsidi biaya personal siswa dan persoalan pada rekrutmen dan kesejahteraan guru.

Selain itu menurut Makmuri Sukarno (Sukarno, 2014), ada empat ketidakseimbangan yaitu kurang seimbangnya partisipasi antara pemerintah, orangtua/ masyarakat dan dunia usaha; kurang seimbangnya penguatan antara afeksi, kognisi dan psikomotor atau value, knowledge dan knowhow; dan kurang seimbangnya penguatan antara kemampuan individual dan kemampuan kelompok serta kurang seimbangnya penguatan antara academic/ school culture dengan socioenvironmental culture.

Lalu bagaimana penyelenggaraan MAN IC saat ini? Apakah penyelenggaraan MAN IC sudah sesuai dengan pedoman penyelenggaraan yang ditetapkan oleh pemerintah? Apa kendala yang dihadapi oleh MAN IC dan bagaimana solusinya? Untuk menjawab pertanyaanpertanyaan itu, perlu dilakukan penelitian evaluasi terhadap penyelenggaraan MAN IC. Penelitian ini bertujuan untuk mengevaluasi madrasah yang sejak awal pendiriannya didesain memiliki keunggulan baik dari sisi input, proses, output maupun outcome yaitu yaitu MAN IC Kota Batam.

\section{KAJIAN TEORI}

\section{Pengertian Evaluasi}

Evaluasi berasal dari dari bahasa Inggris "evaluation" yang diartikan sebagai penaksiran atau penilaian. Evaluasi adalah proses menentukan nilai untuk suatu hal atau objek yang berdasarakan pada acuan-acuan tertentu untuk menentukan tujuan tertentu. Evaluasi bisa juga diartikan sebagai suatu proses sistematis dalam memeriksa, menentukan, membuat keputusan atau menyediakan informasi terhadap program yang telah dilakukan dan sejauh mana sebuah program tercapai. Evaluasi sangat berguna dan memiliki banyak manfaat karena kita bisa mengetahui tingkatan sesuatu sebagai penilaian terhadap apa yang telah dilakukan dan apa yang akan dilakukan.

Pengertian evaluasi menurut KBBI (Kamus Besar Bahasa Indonesia) adalah suatu penilaian dimana penilaian itu ditujukan pada orang yang lebih tinggi atau yang lebih tahu kepada orang yang lebih rendah, baik itu dari jabatan strukturnya atau orang yang lebih rendah keahliannya. Evaluasi adalah suatu proses penelitian positif dan negatif atau juga gabungan dari keduanya. Selanjutnya menurut Undang-Undang RI No. 20 tahun 2003 tentang Sistem Pendidikan Nasional, bab XVI pasal 57 menyatakan evaluasi dilakukan dalam rangka pengendalian mutu pendidikan secara nasional sebagai bentuk akuntabilitas penyelenggara pendidikan kepada pihak-pihak yang berkepentingan.

Beberapa ahli evaluasi mendefinisikan arti "evaluasi" dengan berbagai macam coraknya. Ada yang mengatakan bahwa evaluasi adalah Riset untuk mengumpulkan, menganalisis, dan menyajikan informasi yang bermanfaat mengenai objek evaluasi, selanjutnya menilainya dan membandingkan dengan indikator evaluasi dan hasilnya dipergunakan untuk mengambil keputusan mengenai objek evaluasi tersebut (Wirawan, 2017). Menurut Sukardi (Sukardi, 2014), evaluasi adalah suatu proses mencari informasi tentang objek atau subjek yang dilaksanakan untuk tujuan pengambilan keputusan, atau untuk menilai tingkat keberhasilan suatu program. Evaluasi juga didefinisikan sebagai sebuah proses menentukan hasil yang telah dicapai dari beberapa kegiatan yang direncanakan untuk mendukung tercapainya tujuan (Arikunto, 2010). Pendapat selanjutnya dari Husni (2010), yang menyatakan bahwa "evaluasi adalah suatu proses untuk menyediakan informasi mengenai hasil penilaian atas permasalahan yang ditemukan". Sedangkan menurut Arikunto (Arikunto, 2010) "Evaluasi sebagai sebuah proses menentukan hasil yang telah dicapai dari beberapa kegiatan 
yang direncanakan untuk mendukung tercapainya tujuan.

Dari pengertian oleh beberapa pakar tersebut, secara umum dapat disimpulkan bahwa evaluasi adalah suatu proses kegiatan yang sistematis yang ditujukan untuk mengukur keberhasilan suatu program/kegiatan atau menilai tentang bekerjanya sesuatu dengan mengumpulkan beberapa informasi, dan membandingkannya dengan indikator tertentu, yang hasilnya dapat dijadikan alternatif yang tepat dalam mengambil keputusan. Dalam kaitannya dengan penelitian ini, maka evaluasi yang dimaksud adalah kegiatan untuk mengukur keberhasilan penyelenggaraan program kegiatan dengan mengumpulkan berbagai informasi dari berbagai sumber, dan membandingkan dengan indikator yang ada dalam pedoman penyelenggaraan, yang dapat berguna sebagai pengambilan keputusan terhadap implementasi dan efektifitas program penyelenggaraan kegiatan.

Selain hal di atas, juga dijelaskan tentang evaluasi program, yang didefinisikan sebagai kegiatan sistematis untuk mengumpulkan, mengolah, menganalisis, dan menyajikan data sebagai masukan untuk pengambilan keputusan (Maimun, 2016). evaluasi ini sejalan dengan penelitian ini yaitu untuk melihat secara keseluruhan penyelenggaraan MAN IC Batam sebagai madrasah unggulan berorientasi sains Kementerian Agama saat ini.

Menurut Sudjana, model evaluasi program mencakup lebih dari 50 jenis yang telah dan sedang digunakan dalam evaluasi program. Sebagian model berupa rancangan teoritis yang disusun para pakar, sebagian dikembangkan dari pengalaman evaluasi di lapangan dan sebagian lagi berupa konsep, pedoman dan petunjuk teknis untuk menyelenggarakan evaluasi program. Kemudian lanjutnya, terdapat model-model evaluasi program dengan kategori berikut: (1) Model evaluasi yang terfokus pada pengambilan keputusan (2) Model evaluasi terhadap unsur-unsur program (3) Model evaluasi terhadap jenis kegiatan program (4) Model evaluasi terhadap proses pelaksanaan program (5) Model evaluasi terhadap pencapaian tujuan program, dan (6) Model evaluasi terhadap hasil dan pengaruh program (Lazwardi, 2017).

$\begin{array}{ccc}\text { Evaluasi } & \text { program } & \text { hadir untuk } \\ \text { memberikan } & \text { masukan, } & \text { kajian dan }\end{array}$ pertimbangan dalam menentukan apakah program layak untuk diteruskan atau dihentikan. Dengan kondisi demikian maka istilah evaluasi program menjadi sesuatu yang lumrah di lembaga pendidikan. Kajian ini untuk memberikan ulasan dan pengantar pentingnya sebuah evaluasi program di lembaga pendidikan. Kajian utama dalam tulisan ini adalah pengertian, tujuan dan manfaat dari evaluasi. Tujuan adanya evaluasi program adalah memberikan pertimbangan sebelum adanya keputusan dari pemilik kebijakan. Manfaatnya adalah adanya keputusan yang tepat terhadap program yang sedang atau sudah dilaksanakan (Munthe, 2015).

Menurut Donald B. Yarbrough dkk (Yarbrough, 2010), yang dimaksud dengan program itu adalah Programs as the systematic application of resources guided by logic, beliefs, and assumptions identifying human needs and factors related to them. Program diartikan sebagai aplikasi sistematis dari sumber daya yang di dasarkan pada logika, keyakinan, dan asumsi identifikasi kebutuhan manusia dan faktor-faktor yang berhubungan dengan hal-hal yang sudah disebutkan. Selanjutnya Blaine R. Worten dan James R. Sanders (1973) dalam Muzayanah (2011) mengatakan evaluasi program merupakan proses deskripsi, pengumpulan data dan penyampaian informasi kepada pengambil keputusan yang akan dipakai untuk pertimbangan apakah program perlu diperbaiki, dihentikan atau diteruskan. Adapun perbedaan evaluasi dengan penelitian umumnya terletak pada hasilnya.

\section{Model Evaluasi}

Menurut Wirawan (Wirawan, 2011) mengatakan bahwa: "evaluasi sebagai riset untuk mengumpulkan, menganalisis, dan menyajikan informasi yang bermanfaat mengenai objek evaluasi, menilainya dan membandingkannya dengan indikator evaluasi dan hasilnya dipergunakan untuk mengambil keputusan mengenai objek evaluasi. 
Dalam penelitian evaluasi, banyak sekali dijumpai model-model evaluasi dengan format atau sistematika yang berbeda. Provus mengembangkan model yang disebut Discrepancy Model, Daniel Stufflebeam mengembangkan Context, Input, Process, dan Product (CIPP) Evaluation Model (Hill, 2008), Robert Stake's mengembangkan model Responsive Evaluation, Michael Scriven mengembangkan model Formatif Summatif Evaluation, Edward L. Thorndike dan Robert L. Ebel mengembangkan Measurement Model, Stake mengembangkan Countenance Evaluation model, dan Michael Scriven's mengembangkan model Goal-Free Evaluation Approach (Muryadi, 2017)

Model yang dikembangkan Stufflebeam banyak digunakan dalam penelitian kebijakan, diantaranya penelitian yang dilakukan oleh (Qowaid, 2012; Munawirah, 2013; Tuung, 2014; Zainuddin, 2016; Dudin, 2017; Indriani and Satrianawati, 2018). Begitu juga dalam penelitian ini, CIPP dipilih karena lebih komprehensif jika dibandingkan dengan model evaluasi lainnya. Model CIPP merupakan model evaluasi di mana evaluasi dilakukan secara keseluruhan sebagai suatu sistem. Evaluasi model CIPP merupakan konsep yang ditawarkan oleh Stufflebeam dengan pandangan bahwa tujuan penting evaluasi adalah bukan membuktikan tetapi untuk memperbaiki. Keunikan model ini adalah pada setiap evaluasi terkait pada perangkat pengambil keputusan yang menyangkut perencanaan dan operasional sebuah program.

Secara sederhana Muryadi (2017) menjelaskan bahwa Evaluasi konteks mencakup analisis masalah yang berkaitan dengan lingkungan program atau kondisi objektif yang akan dilaksanakan. Berisi tentang analisis kekuatan dan kelemahan obyek tertentu, mengidentifikasi peluang dan menilai kebutuhan. Suatu kebutuhan dirumuskan sebagai suatu kesenjangan kondisi nyata dengan kondisi yang diharapkan. Sedangkan Evaluasi input meliputi analisis personal yang berhubungan dengan bagaimana penggunaan sumber-sumber yang tersedia, alternatifalternatif strategi yang harus dipertimbangkan untuk mencapai suatu program.
Adapun Evaluasi proses merupakan evaluasi yang dirancang dan diaplikasikan dalam praktik implementasi kegiatan. Termasuk mengidentifikasi permasalahan prosedur baik tatalaksana kejadian dan aktivitas. Setiap aktivitas dimonitor perubahanperubahan yang terjadi secara jujur dan cermat. Pencatatan aktivitas harian demikian penting karena berguna bagi pengambil keputusan untuk menentukan tindak lanjut penyempurnaan. Evaluasi sebagai proses menilai sesuatu berdasarkan standar obyektif yang telah ditetapkan, kemudian diambil keputusan atas obyek yang dievaluasi. Evaluasi proses juga dapat dipahami sebagai evaluasi untuk mengidentifikasi atau memprediksi dalam proses pelaksanaan, seperti adanya cacat dalam desain prosedur atau implementasinya (Munawiroh, 2013).

Terakhir Evaluasi produk merupakan kumpulan deskripsi dan "judgment outcomes" dalam hubungannya dengan konteks, input, dan proses, kemudian diinterpretasikan harga dan jasa yang diberikan. Evaluasi produk adalah evaluasi mengukur keberhasilan pencapaian tujuan. Evaluasi ini merupakan catatan pencapaian hasil dan keputusan-keputusan untuk perbaikan dan aktualisasi. Aktivitas evaluasi produk adalah mengukur dan menafsirkan hasil yang telah dicapai.

Evaluasi konteks yang dimaksud dalam penelitian ini adalah evaluasi terhadap kelemahan dan kekuatan yang terjadi pada penyelenggaraan MAN IC Batam, termasuk menganalisis adanya peluang dan ancaman, dengan melihat pada berbagai aspek yang meliputi visi, misi, tujuan, dasar kebijakan (yuridis, filosofis, sosiologis), penyelenggaraan MAN IC Batam.

Evaluasi input pada penelitian ini bertujuan menyediakan informasi untuk menentukan bagaimana menggunakan sumber daya yang tersedia dalam mencapai tujuan program, yang meliputi analisis personal yang berhubungan dengan bagaimana penggunaan sumber daya yang tersedia, alternatif-alternatif strategi untuk mencapai tujuan, menilai kapabilitas sistem, alternatif strategi program, desain prosedur untuk strategi implementasi, pembiayaan dan penjadwalan. Dalam unsur evaluasi input juga meliputi seluruh sumber 
daya yang ada di madrasah (sumber daya manusia; sarana dan prasarana; pembiayaan; kurikulum; berbagai prosedur dan aturan yang diperlukan dalam penyelenggaraan MAN IC Batam).

Evaluasi proses dalam penelitian ini untuk mengetahui sejauh mana penyelenggaraan pembelajaran MAN IC Batam yang ditetapkan apakah sesuai rencana atau jadwal yang sudah dibuat sebelumnya dan apa kendala yang dihadapi. Proses pembelajaran dalam hal ini mencakup: 1) perencanaan (penyusunan rencana pembelajaran dan kalender akademik); 2) pelaksanaan pembelajaran (penetapan dan pengembangan materi/ kurikulum, penggunaan pendekatan dan metode pembelajaran, penentuan KKM dan upaya mencapai KKM, penggunaan dan pengembangan sarana/alat pembelajaran, program-program pembelajaran mencakup program kurikuler, ekstrakurikuler, penguatan, pembiasaan, program keasramaan/keagamaan dll); 3) penilaian (alat dan model evaluasi, capaian hasil dan dampak); Penguatan pembelajaran melalui pengelolaan asrama. Sedangkan yang dimaksud dengan evaluasi produk dalam penelitian ini adalah kegiatan untuk mengetahui keberhasilan penyelenggaraan MAN IC Batam dan kendalanya, dilihat dari prestasi akademik, prestasi non akademik, capaian perkembangan kemampuan siswa, peningkatan kemampuan religi, dan mobilitas alumni.

\section{Pengertian Penyelenggaraan MAN IC}

Menurut KBBI, penyelenggaraan adalah proses, cara, perbuatan menyelenggarakan di berbagai-bagai arti seperti pelaksanaan, atau penunaian. Penyelenggara Pendidikan Madrasah adalah kegiatan pelaksana komponen sistem pendidikan pada bentuk pendidikan madrasah agar proses pendidikan dapat berlangsung sesuai tujuan pendidikan nasional. Madrasah adalah pendidikan formal dalam binaan kementerian agama yang menyelenggarakan pendidikan umum dan kejuruan dengan kekhasan agama Islam yang mencakup RA, MI, MTs, MA dan MAK. Penyelenggaraan Pendidikan Madrasah adalah kegiatan pelaksanaan komponen sistem pendidikan pada Raudhatul Athfal, Madrasah Ibtidaiyah, Madrasah Tsanawiyah, Madrasah Aliyah, dan Madrasah Aliyah Kejuruan agar proses pendidikan dapat berlangsung sesuai dengan tujuan pendidikan nasional. (Peraturan Menteri Agama Republik Indonesia Nomor 90 Tahun 2013 Tentang Penyelenggaraan Pendidikan Madrasah).

Dalam Peraturan Menteri Agama Nomor 42 Tahun 2017 Bab I Pasal 1 Ayat 2, tentang Organisasi dan Tata Kerja Madrasah Aliyah Negeri Insan Cendekia, MAN IC adalah satuan pendidikan jenjang menengah, yang memadukan PAI dengan pengayaan pada bidang ilmu pengetahuan dan teknologi, sebagai ciri khas utamanya, atau satuan pendidikan formal pada Kemenag yang menyelenggarakan pendidikan umum dengan kekhasan agama Islam, diselenggarakan pada jenjang menengah, berbasis asrama, dan mengembangkan keunggulan akademik. MAN IC memiliki keunggulan dibanding dengan madrasah lainnya, antara lain: 1) Pengembangan kurikulum dan pembelajaran mengacu pada Standar Mutu (SM) di atas SNP dan berbasis keunggulan lokal; 2) dikelola berbasis TIK dengan dukungan pendidik yang memenuhi kualifikasi dan kompetensi yang dipersyaratkan; 3) Fasilitas pembelajaran memenuhi persyaratan kesehatan, keselamatan, kenyamanan, dan keamanan; 4) peserta didik wajib tinggal diasrama yang dikelola secara profesional; 5) peserta didik wajib berkomunikasi dengan bahasa Indonesia, Inggris dan Arab.

MAN IC sudah berdiri sejak tahun 2001 dan kini terus berkembang. Saat ini sudah ada 24 MAN IC yang tersebar di wilayah Indonesia. Keberadaan MAN IC sebagai madrasah yang memadukan antara IPTEK dan IMTAK memiliki daya tarik tersendiri untuk terus dikaji. Banyak studi sudah dilakukan oleh para peneliti dengan berbagai lokus seperti penelitian tentang manajemen MAN IC, Determinasi Madrasah Efektif (Taufik, 2014), Manajemen Madrasah Berprestasi, Mandiri, Islami dan Berdaya Saing Global (Harahap, 2018), Manajemen Prestasi Siswa MAN IC Kota Kendari (Nurhalimah, 2019), Manajemen Kepala Madrasah Dalam Sistem Penjaminan Mutu Madrasah (Muhaimin, 2019), Evaluasi Pendidikan Terkemuka (Evi, 2019), Orientasi Pilihan Studi dan Profesi Siswa MAN IC Serpong (Hayadin, 2019), Effective School Management at MAN 
IC Gorontalo (Najamuddin, 2020), Model sekolah Efektif (Musli, 2018), dan masih banyak studi-studi lainnya.

Penelitian ini mengkaji pada scope yang lebih luas yaitu evaluasi penyelenggaraan MAN IC, dengan melihat aspek konteks, input, proses, output dan outcome. Penelitian ini mengambil lokasi pada MAN IC Kota Batam yang merupakan generasi ketiga pendirian MAN IC.

\section{METODOLOGI}

Penelitian ini menggunakan pendekatan kualitatif untuk mendeskripsikan suatu proses kegiatan pendidikan berdasarkan apa yang terjadi di lapangan sebagai bahan kajian lebih lanjut untuk menemukan kekurangan dan kelemahan pendidikan sehingga dapat ditentukan upaya penyempurnaannya. Penelitian ini dilakukan di Kota Batam pada bulan Juni 2019. Metode penelitian yang digunakan adalah metode deskriptif kualitatif. Metode ini digunakan untuk menggambarkan suatu gejala, peristiwa, dan kejadian yang terjadi pada masa sekarang. Menurut Sukmadinata (2010) penelitian deskriptif memiliki beberapa variasi, diantaranya studi perkembangan yang tidak hanya bisa mendeskriptifkan sesuatu keadaan saja, tetapi juga bisa mendeskripsikan keadaan dalam tahapan-tahapan perkembangannya. Teknik pengumpulan data yang digunakan dalam penelitian ini adalah pedoman wawancara, studi dokumentasi, dan observasi. Studi dokumentasi digunakan untuk mendapatkan data-data sekunder. Sedangkan wawancara diarahkan kepada seluruh responden yang dapat dipertimbangkan memenuhi syarat untuk memberikan pandangan dan penilaian terhadap penyelenggaraan MAN IC yaitu Kepala dan wakil kepala MAN IC Kota Batam, Kepala Tata Usaha, guru, peserta didik, dan orang tua siswa. Metode observasi digunakan untuk pengamatan terhadap objek-objek penelitian yang penting yang akan memperkaya data penelitian. Data dianalisis menggunakan teknik analisis deskriptif kualitatif. Analisis deskriptif digunakan untuk menjelaskan secara utuh pengelolaan MAN IC yang didasarkan kepada indikator tertentu. Pengukuran sejauh mana tujuan pelaksanaan program/kegiatan tercapai digunakan sebagai bahan pertimbangan dalam mengambil suatu kebijakan atau keputusan.

\section{HASIL}

\section{Evaluasi Konteks}

Jika berbicara konteks, maka tidak bisa lepas dari sejarah pendirian dan perkembangannya. Perjuangan untuk mewujudkan "Madrasah Negeri Unggulan" di Provinsi Kepri telah dimulai sejak tahun 2004. Cikal bakal MAN Insan Cendekia Batam telah dicetuskan sejak periode Menteri Agama RI (Maftuh Basyuni). Saat itu ada tawaran untuk membangun sebuah lembaga pendidikan Islam yang berbasis keunggulan. Drs. H. Nyat Kadir, Walikota Batam saat itu, ditawarkan untuk membangun madrasah yang bernama "Magnet School", dengan anggaran pinjaman lunak dari Islamic Development Bank (IDB). Akan tetapi rencana tersebut tidak mendapat tanggapan positif dari anggota DPRD Batam.

Seiring perjalanan waktu, Menteri Agama kembali menawarkan agar Batam membangun madrasah unggulan, yang diberi nama "Madrasah Bertaraf Internasional (MBI)'. Pada saat itu (2008), Dirjen Pendidikan Islam, Prof. Muhammad Ali, telah menandatangani MoU bersama Walikota Batam, Drs. Ahmad Dahlan, MH. Madrasah Bertaraf Internasional itu rencananya akan dibangun di atas lahan hibah Otoritas Batam ke Pemkot Batam, seluas 20 hektar. Namun sekali lagi, MBI gagal dibangun karena konsep yang belum tuntas.

MAN Insan Cendekia Batam adalah proyek 3 Menteri (Muhammad Maftuh Basyuni, SH - Drs. Suryadharma Ali, M.Si Drs. H. Lukman Hakim Saifudin), 2 Gubernur (Drs. H. Ismeth Abdullah - Drs. H. Muhammad Sani), 3 Kanwil ( Drs. H. Razali Jaya - H. Andalin H. Umar - Drs. H. Marwin Jamal), 3 Walikota (Drs. H. Nyat Kadir - Drs. H. Ahmad Dahlan, M.H., Ph.D - H. Muhammad Rudi, SE.,MM), dan 3 Kakankemenag (Drs.H. Abd. Razak.Z. MM Drs.H. Khudri Syam - Drs.H. Zulkifli Aka, M.Si).

Maftuh Basyuni digantikan oleh Suryadharma Ali, MBI dihidupkan kembali dengan nama MAN Insan Cendekia (MAN IC), merujuk dan melanjutkan MAN IC yang sebelumnya dibangun oleh Pak Habibie, seperti MAN IC Serpong dan Gorontalo. 
Pada tahun 2013, kembali Batam mendaftarkan diri untuk mendapatkan proyek MAN IC ini dengan berbagai jalan yang ditempuh, yang didukung juga oleh Bapak Hardi Selamat Hood (Anggota DPD RI asal Kepri), agar proyek ini tidak gagal lagi. Pada waktu itu sesungguhnya Menteri Agama RI (Suryadharma Ali) telah mengabulkan berdirinya MAN IC Batam dan telah mengalokasikan anggaran sebesar 12 Milyar rupiah. Namun masih ada kendala teknis, sehingga dana tersebut dikembalikan ke negara, dan pembangunan MAN IC Batam belum terealisasi.

Pada tahun 2014, Kemenag Batam kembali mengusulkan pembangunan MAN IC Batam dan mendapat tanggapan positif dari Kementerian Agama RI, sehingga pembangunan MAN IC Batam pun dimulai, ditandai dengan peletakan batu pertama langsung oleh Menteri Agama RI H. Lukman Hakim Saifudin, pada tanggal 15 November 2014 dengan mengalokasikan anggaran untuk pembangunan asrama, RKB, dan perataan lahan, namun proyek yang berhasil dilelang hanya meratakan lahan, seluas 10 hektar.

Pada tahun 2015, Kementerian Agama Kota Batam membangun satu unit asrama dengan 32 kamar dan satu unit gedung belajar dengan 12 RKB dari dana APBN. Pemerintah Provinsi Kepri membangun sebagian pagar keliling area MAN IC Batam, dari APBD Provinsi sebesar 1.3 milyar rupiah. Pemerintah Kota Batam menyelesaikan pembebasan lahan seluas 10 hektar dan telah dibuat surat hibahnya dari Pemkot Batam ke Kementerian Agama RI.

Pada tahun 2016, MAN IC Kota Batam mulai menerima siswa dan melanjutkan pembangunan sarana prasarana, diantaranya pembangunan masjid dengan anggaran 4 milyar dari APBD Kota Batam, disamping pembangunan Pemerintah Kota Batam membangun jalan lingkungan sebesar 1,4 Milyar, dan juga instalasi listrik. Tahun 2017 Pemerintah Provinsi Kepri melaksanakan pembangunan pintu gerbang sebesar 720 juta Rupiah, Tahun 2017 juga melaksanakan pembangunan RKB Lanjutan dan Asrama Putra Tahap 1.

Pada Tahun 2018 MAN IC Kota Batam mulai melakukan pembangunan Laboratorium
Terpadu dan Perpustakaan menggunakan Anggaran Surat Berharga Syariah (SBSN) dan juga melaksanakan pembangunan Asrama Putra Lanjutan. Dan pada tahun 2018 MAN IC Kota Batam melakukan MoU dengan Pemerintah Kota Batam pada tanggal 7 September 2018 yang bertujuan untuk kerja sama dalam penyediaan infrastruktur, sarana dan prasarana pendidikan madrasah dan kerja sama penyelenggaraan dan pengelolaan pendidikan Madrasah selama jangka waktu 5 tahun sejak ditandatangani dan dapat diperpanjang sesuai dengan kebutuhan dan atas kesepakatan bersama. Dan Pada tahun 2019 ini MAN IC Kota Batam mulai melakukan pembangunan gedung pusat layanan kegiatan siswa dan gedung pusat pembelajaran terpadu menggunakan Surat Berharga Syariah Negara (SBSN) tahun anggaran 2019.

MAN IC Kota Batam merupakan unit pelaksana teknis bidang pendidikan berbentuk satuan pendidikan madrasah akademik jenjang pendidikan menengah pada jalur pendidikan formal pada Kementerian Agama, berada di bawah dan bertanggung jawab kepada Direktur Jendral Pendidikan Islam Kementerian Agama RI. MAN Insan Cendekia Kota Batam dibangun atas kerja sama yang baik antara Pemerintah Kota Batam, Kantor Wilayah Kementerian Agama Provinsi Kepulauan Riau dan Kementerian Agama RI yang berlokasi di Jalan Hang Lekiu, RT. II/RW X Kel. Sambau Kecamatan Nongsa Kota Batam, Provinsi Kepulauan Riau.

\section{Visi dan Misi}

Visi MAN IC Kota Batam adalah terwujudnya sumber daya manusia yang berkualitas tinggi dalam keimanan dan ketakwaaan, menguasai ilmu pengetahuan dan teknologi, mampu berkomunikasi dalam bahasa Internasional serta mampu mengaktualisasikan diri dalam masyarakat. Dan misi MAN IC, yaitu (1) Menyiapkan calon pemimpin masa depan yang menguasai ilmu pengetahuan dan teknologi, mempunyai daya juang tinggi, kreatif, inovatif, proaktif, dan mempunyai landasan iman dan takwa yang kuat, (2) Menumbuh kembangkan minat, bakat, dan potensi peserta didik untuk meraih prestasi pada tingkat nasional sampai internasional, (3) Meningkatkan pengetahuan dan kemampuan 
profesional pendidik dan tenaga kependidikan sesuai dengan perkembangan dunia pendidikan, (4) Menjadikan MAN Insan Cendekia sebagai lembaga pendidikan yang mempunyai tata kelola yang baik dan mandiri, dan (5) Menjadikan MAN Insan Cendekia sebagai model dalam pengembangan pembelajaran IPTEK dan IMTAK bagi lembaga pendidikan lainnya.

\section{Tujuan dan Target}

Tujuan penyelenggaraan MAN IC Kota Batam antara lain, yaitu (1) Menghasilkan lulusan yang berkarakter Islami, berwawasan keindonesiaan, kebangsaan, internasional, dan kemanusiaan, (2) Menghasilkan lulusan yang mengua sai dasar-dasar keilmuan keislaman, sains, teknologi, ilmu sosial, dan seni budaya untuk meraih prestasi baik tingkat nasional maupun internasional, dan (3) Membentuk lulusan yang berkarakter dan mampu melakukan perubahan yang didasari oleh prinsip-prinsip Islam rahmatan lil'alamin. Sedangkan target yang ingin dicapai MAN IC Kota Batam yaitu (1) Diperolehnya prestasi akademik dan non akademik yang optimal oleh peserta didik MAN Insan Cendekia, (2) Diterimanya lulusan MAN Insan Cendekia di Perguruan Tinggi berkualitas baik di dalam maupun di luar negeri lebih dari $90 \%$ tiap tahun, (3) Diperolehnya prestasi akademik yang baik bagi alumni MAN Insan Cendekia selama studi di Perguruan Tinggi, dan (4) Terciptanya kehidupan religius di lingkungan madrasah dengan bercirikan perilaku rajin beribadah, rajin belajar, ikhlas, mandiri, sederhana, ukhuwah dan kebebasan berkreasi.

\section{Evaluasi Input}

Evaluasi input merupakan evaluasi yang bertujuan menyediakan informasi untuk menentukan bagaimana menggunakan sumberdaya yang tersedia dalam mencapai tujuan program. Komponen evaluasi masukan meliputi: (1) Sumber daya manusia; (2) Kurikulum; (3) Sarana dan Prasarana; dan (4). Dana dan Anggaran.

\section{Sumber Daya Manusia}

Sumber daya Manusia MAN IC Kota Batam terdiri dari peserta didik dan tenaga
Pendidik dan Kependidikan. Peserta didik MAN IC Batam berjumlah 269 orang yang terdiri dari kelas X: 96 orang, Kelas XI: 96 orang, dan Kelas X11: 77 orang. Jumlah rombongan belajar sebanyak12 rombel. Jika dilihat dari animo masyarakat, orang tua yang ingin memasukkan anaknya ke MAN IC Batam terlihat cukup tinggi. Hal ini terlihat dari jumlah pendaftar dan jumlah anak yang diterima. Pada tahun pertama (TP 2016/2017) jumlah pendaftar sebanyak 615 orang dan yang diterima hanya 77 orang. Pada tahun kedua (TP 2017/2018) jumlah pendaftar sebanyak 416 orang dan yang diterima 96 orang, dan pada tahun ketiga (2018/2019) jumlah pendaftar sebanyak 369 orang dan yang diterima 96 orang. Namun dari data tersebut memunculkan pertanyaan mengapa jumlah peminat semakin turun sedangkan jumlah peserta didik yang diterima bertambah. Apakah ini sebagai dampak dari semakin banyaknya MAN IC yang berdiri di berbagai propinsi atau ada faktor lainnya. Pada tahun 2016 jumlah MAN IC berjumlah 17 unit, pada tahun 2017 jumlah MAN IC menjadi 22 unit, dan pada saat ini jumlah MAN IC bertambah menjadi 24 unit.

Untuk mendapatkan input seperti yang diharapkan, rekruitmen siswa dilakukan dengan sistem seleksi yang sangat ketat. Untuk MAN IC Batam kapasitas peserta didik tahun pelajaran 2018/2019 sebanyak 96 orang. Pendaftaran peserta didik baru MAN IC dilakukan melalui dua jalur yaitu Jalur Tes dan Jalur Prestasi. Calon peserta harus memenuhi persyaratan pendaftaran baik persyaratan administrasi atau persaratan umum dan persyaratan khusus untuk jalur prestasi. Pendaftaran bisa dilakukan secara online di www.icbatam.sch.id.

Seleksi berkas dilakukan oleh Direktorat Madrasah dengan meneliti pemenuhan persyaratan dan memeriksa data online yang diatur pelaksanaannya dalam 3 zona seleksi. Untuk Man IC Batam masuk dalam zona Jambi yang meliputi seluruh wilayah Sumatera. Bagi calon peserta didik yang lolos seleksi berkas harus mengikuti tahapan selanjutnya yaitu tes tertulis. Materi tes tertulis ini meliputi Tes Potensi Belajar (TPB) dan Tes Akademik untuk bidang studi matematika, Pengetahuan Dasar 
(IPA dan IPS), Bahasa Inggris, Pendidikan Agama Islam, dan Bahasa Arab.

Setelah diterima menjadi peserta didik, calon peserta didik yang telah melakukan daftar ulang akan menempati asrama madrasah. Kegiatan dilakukan selama satu hari, diawali dengan pertemuan antara calon peserta didik baru, orang tua/wali dan pihal madrasah serta komite madrasah. Tahap selanjutnya adalah tes minat dan bakat. Tes minat dan bakat bagi peserta didik baru MAN IC Batam dilaksanakan sebagai bentuk penguatan peminatan peserta didik agar selaras dengan talenta dan kemampuan dasar yang telah dimiliki sesuai dengan pengalaman belajar sebelumnya. Kegiatan selanjutnya adalah madrasah mengadakan masa ta'aruf. Kegiatan ini dalam bentuk ceramah/seminarisasi, game/permainan untuk menciptakan keakraban dan kerja sama serta kekompakan antar sesama peserta didik baru MAN Insan Cendekia Kota Batam selama 3 hari. Penyelenggaraan Masa Ta'aruf Siswa Madrasah Aliyah (MATSAMA) merupakan kegiatan yang dilaksanakan disekolah guna menyambut kedatangan siswa baru dalam rangka pengenalan lingkungan madrasah yang didudukinya. Kemudian peserta didik yang telah melalui proses awal masuk madrasah wajib mengikuti kegiatan matrikulasi. Kegiatan matrikulasi dilaksanakan dengan tujuan untuk menyetarakan kemampuan dasar peserta didik sebelum dimulai proses pembelajaran sesuai kurikulum di MAN Insan Cendikia.

Kompilasi hasil tes minat dan bakat serta tes kompetensi mata pelajaran, nilai UN dan nilai rata-rata rapor MTs/SMP, menjadi dasar penentuan peserta didik melalui keputusan madrasah yang bersifat mutlak dan tidak bisa diganggu gugat.

Tenaga Pendidik dan Kependidikan di MAN IC ini berjumlah 44 orang. Tenaga pendidik berjumlah 29 orang yang terdiri dari 15 laki-laki dan 14 perempuan. Sebanyak 10 orang berstatus PNS dan 19 orang berstatus non PNS. Dari sisi latar belakang pendidikan, sebanyak 23 guru berpendidikan S1 dan 6 guru berpendidikan S2/S3. Tidak ada mismatch, jumlah memadai, hanya sering keluar karena diterima sebagai PNS. Sedangkan tenaga kependidikan berjumlah 15 orang yang terdiri dari 4 karyawan Tata Usaha (TU), 1 Perawat, 6
Security, 3 Cleaning Service, dan 1 Sopir. Dari sisi latar belakang pendidikan, sebanyak 4 orang berpendidikan S, 1 orang berpendidikan Diploma (D3), 9 orang berpendidikan SMA, dan 1 orang berpendidikan SD. Dari jumlah tersebut hanya satu orang yang berstatus PNS dan 14 lainnya berstatus non PNS. Berdasarkan jenis kelamin tenaga kependidikan, sebanyak 10 orang Laki-laki dan perempuan 5 orang. Pengasuh Asrama terdiri dari 2 orang laki-laki dan satu orang perempuan. Semuanya berpendidikan $\mathrm{S} 1$.

Rekruitmen tenaga pendidik dan kependidikan di MAN IC menjadi kewenangan pemerintah pusat (Dirjen Pendidikan Islam). Jumlah tenaga pendidikan dan kependidikan yang direkrut sesuai dengan kebutuhan MAN IC. Rekruitmen ini dilakukan melalui tiga tahapan yaitu seleksi administrasi, tes tertulis, dan wawancara. Proses rekruitmen guru ini dilakukan serentak secara nasional yang dilakukan oleh Tim Kemenag Pusat dan Tim dari Madrasah yang ditunjuk oleh kepala Madrasah. Proses seleksi ini dilaksanakan di MAN IC Kota Batam. Tahapan rekruitmen guru ini sudah dilakukan sesuai dengan prosedur yang ditetapkan. Guru hasil rekruitmen juga sesuai kualifikasi dan memiliki kompetensi yang diharapkan. Tidak ada guru yang mismatch di MAN IC Kota Batam. Semua mengajar sesuai dengan latar belakang pendidikannya dan semua mata pelajaran terpenuhi. Namun demikian persoalan yang sering muncul terkait dengan tenaga pendidik adalah masalah status guru. Guru yang lolos tes dan diterima untuk mengajar di MAN IC berstatus guru tetap MAN IC dan bukan PNS. Hal ini menjadi problem tersendiri bagi MAN IC karena para guru masih tergiur untuk mengikuti Tes PNS. Mereka yang mengikuti tes dan lolos PNS tidak ditempatkan di MAN IC. Untuk memenuhi kebutuhan guru di MAN IC Batam, harus melakukan perekrutan guru baru lagi. Seringnya ganti guru sedikit banyak akan berdampak terhadap pembelajaran yang berkelanjutan.

\section{Kurikulum}

MAN IC Batam melaksanakan kurikulum nasional yang ditetapkan oleh pemerintah yang dimodifikasi sesuai dengan visi, misi, tujuan dan target madrasah. Modifikasi kurikulum 
tersebut berupa penguatan konsep dasar pengurusan IPTEK (basic of science and technology) dan kurikulum khas bidang keasramaan.

Pembelajaran dilakukan secara inspiratif menyenangkan, interaktif, menantang, memotivasi dan memberi ruang bagi prakarsa kreativitas dan kemandirian anak sesuai potensi. Minat, bakat dan kebutuhannya untuk tumbuh kembang secara optimal. Pengembangan kurikulum mengedepankan pengalaman pribadi peserta didik melalui proses mengamati, menanya, menalar, dan mencoba (observation based learning), yang didukung partisipasi aktif orang tua, media massa dan lingkungan sekitar.

Pengembangan Kurikulum MAN IC Batam yang beragam mengacu pada standar nasional pendidikan untuk menjamin pencapaian tujuan pendidikan nasional. Kurikulum MAN IC Batam dikembangkan dengan prinsip diversifikasi sesuai dengan satuan pendidikan, potensi daerah, dan peserta didik. Pengembangan kurikulum secara berdiversifikasi dimaksudkan untuk memungkinkan penyesuaian program pendidikan pada MAN IC Batam dengan kondisi, karakteristik dan kekhasan potensi serta kebutuhan yang ada di daerah.

\section{Sarana Prasarana}

Sarana dan Prasarana adalah sesuatu yang sangat penting dan mesti ada dalam menunjang setiap kegiatan organisasi atau lembaga, karena dalam menjalankan organisasi atau lembaga tersebut diperlukan aspek-aspek pendukung dan penunjang yang sangat berpengaruh dalam melancarkan sebuah kegiatan organisasi atau lembaga. Kualitas hasil produk sebuah organisasi/lembaga tersebut sangat ditentukan oleh bagaimana sarana dan prasarana penunjang tersebut dikelola dan di atur dengan baik dan benar.

MAN IC kota Batam berdiri diatas lahan seluas $10.575 \mathrm{M} 2$ yang terdiri dari $8.575 \mathrm{M} 2$ luas bangunan, $500 \mathrm{M} 2$ luas halaman, $500 \mathrm{M} 2$ luas lapangan, $500 \mathrm{M} 2$ luas kebun, dan $500 \mathrm{M} 2$ luas taman. Lahan ini merupakan tanah wakaf dari Pemerintah daerak kota Batam yang berlokasi di Jl Hang Lekie RT II RW X Kelurahan Sambau, kecamatan Nongsa Kota
Batam Kepulauan Riau. Lahan hibah ini masih dalam proses pembuatan sertifikasi.

Sarana prasarana MAN IC Batam terdiri dari Gedung Sekolah: Ruang kelas (12), Ruang kamad, Ruang Guru, R. TU/kantor, R. Tamu (guest house), R. Tunggu, R. Laboratorium IPA, R. Laboratorium Bahasa, R. Laboratorium Agama, Perpustakaan, Kantin, Ruang Makan, Ruang Dapur, asrama ptra dan putri, asrama guru dan kepala madrasah, lapangan sepak bola, ruang bimbingan konseling, ruang OSIS/Pramuka, Ruang Komputer, Ruang UKS, R. Kesenian/berkreasi, Masjid, Tempat Wudlu, dan Kamar Mandi. Semua masih dalam kondisi baik, kecuali koridor menuju asrama yang sedikit ada kebocoran. Asrama guru dan akryawan masih sangat kurang (baru ada 4 unit) dan Sarana dan Infrastruktur Penunjang : Pintu gerbang masuk, Pagar keliling sekolah, Jalan di lingkungan madrasah, Sistem Drainase, Taman sekolah, Hutan biologi/green house, Air Bersih, Voltase Daya Listrik, Internet, dan alat komunikasi.

Pengelolaan sarana-prasarana MAN IC dilakukan bersama-sama antara pemerintah Pusat, Pemerintah Daerah, dan masyarakat sesuai dengan Keputusan Direktur Jenderal Pendidikan Islam Nomor 3188 Tahun 2013 tentang Pedoman Pembangunan Madrasah Aliyah Negeri Insan Cendikia. Sampai saat ini kondisi kebutuhan sarana prasarana MAN IC Batam masih banyak karena madrasah ini masih relative muda (berdiri tahun 2016). Asrama yang ada baru 4 unit yang diberikan untuk kepala madrasah, guru dan pembina asrama. Banyak guru yang belum mendapatkan asrama. Idealnya seluruh guru dan karyawan MAN IC mendapatkan fasilitas asrama karena kegiatan dilakukan mulai dini hari sampai malam hari.

Pemenuhan sarana prasarana MAN IC Batam juga menjadi tanggungjawab pemerintah pusat dibantu oleh pemerintah daerah. Kebutuhan dasar sarana prasarana di MAN IC Batam yang menunjang proses belajar mengajar sudah terpenuhi. Pemenuhan kelengkapan fasilitas secara bertahap diusulkan oleh madrasah sesuai dengan prioritas kebutuhan dan kesediaan anggaran pemerintah pusat. Pada tahun ini madrasah mengusulkan pembangunan pusat layanan kegiatan siswa dan pusat pembelajaran terpadu. 


\section{Pembiayaan}

Sumber dana utama MAN IC Batam berasal dari APBN dan dana dari masyarakat/orang tua siswa. Penggunaan dana APBN antara lain untuk sarana prasarana penunjang, Penyelenggaraan Operasional MA berasrama (MA Unggulan/Insan Cendikia, dan Operasional dan Pemeliharaan Kantor. Sumber dana yang kedua adalah dana yang berasal dari orang tua siswa. Dana ini dikelola oleh komite madrasah. Dana yang dikelola ini merupakan biaya personal peserta didik yang meliputi biaya awal tahun pelajaran dan biaya personal bulanan. Biaya awal tahun pelajaran mencakup biaya seragam sekolah untuk laki-laki sebesar Rp 2.517.000 dan untuk perempuan sebesar Rp 2.807.000; Biaya kebutuhan individu sebesar Rp 540.000 dan biaya kebutuhan asrama sebesar Rp 42.500. Biaya personal bulanan mencakup biaya hidup sebesar Rp 1.295.000 yang terdiri dari biaya makan 3 kali sehari dan snack 2 kali sehari sebesar Rp 1.200.000/perbulan, biaya air minum $\mathrm{Rp} 25.000 /$ bulan dan biaya binatu sebesar Rp 70.000/bulan dan biaya peningkatan mutu sebesar Rp 130.000. Jadi total jumlah kebutuhan biaya personal individu sebesar Rp 1.450.000/bulan.

Secara umum pembiayaan penyelenggaraan MAN IC Batam sudah terpenuhi terutama anggaran yang berasal dari pemerintah. Pemerintah kota Batam membantu pembiayaan dalam sarana prasarana seperti pembuatan pagar dan gapura, akses jalan pemerintah kota dan pemerintah provinsi, masjid, instalasi listrik dan sebagainya. Biaya personal peserta didik dibebankan pada orang tua peserta didik. Bagi peserta didik yang tidak mampu memenuhi biaya personalnya bisa mengajukan bantuan kepada pemerintah. Selama ini ada 29 peserta didik yang mendapatkan bantuan yang terdiri dari Kartu Indonesia Pintar (KIP) 6 anak, Surat Keterangan tidak mampu (SKTM) 22 anak, Kartu perlindungan Siswa (KPS) 2 anak, Program Keluarga Harapan1 anak, Kartu Keluarga Sejahtera (KKS) 1 anak, Kartu Indonesia Sehat (KIS) 2 anak. Untuk kebutuhan personal anak, MAN IC Batam memberikan subsidi silang untuk memenuhi kebutuhan personal anak. MAN IC batam juga melakukan kerjasama dengan para wisatawan untuk menjadi orang tua asuh anak.

\section{Evaluasi Proses}

Evaluasi proses digunakan untuk mendeteksi atau memprediksi rancangan prosedur atau rancangan implementasi selama tahap implementasi, menyediakan informasi untuk keputusan program dan sebagai rekaman atau arsip prosedur yang telah terjadi. Evaluasi proses meliputi koleksi data penilaian yang telah ditentukan dan diterapkan dalam praktek pelaksanaan program. Rusman menyebutkan bahwa evaluasi proses pembelajaran dilakukan untuk menentukan kualitas pembelajaran secara keseluruhan, mencakup tahap perencanaan proses pembelajaran, pelaksanaan proses pembelajaran, dan penilaian hasil pembelajaran (Rusman, 2011).Pada dasarnya evaluasi proses untuk mengetahui sampai sejauh mana rencana telah diterapkan dan komponen apa yang perlu diperbaiki.

Kegiatan belajar mengajarkan di MAN IC Batam dilaksanakan mulai pukul 07.00-15.15 WIB. Kegiatan ekstrakurikuler, penguatan dan pembinaan baik mata pelajaran umum maupun mata pelajaran agama dilaksanakan diluar jam KBM. Sistem penyelenggaraan pendidikan pada MAN IC menggunakan pendekatan keterpaduan antara sistem madrasah dan pondok pesantren (asrama). Kurikulum MAN IC merupakan kurikulum yang terintegrasi sehingga struktur kurikulumnya meliputi pembelajaran siang dan malam hari. Pembelajaran siang hari meliputi seluruh mata pelajaran, sedangkan pembelajaran malam hari khusus untuk pembelajaran agama Islam yang bersifat aplikatif dan psikomotorik. Secara umum struktur kurikulum MA untuk mata pelajaran umum mengacu pada kurikulum 2013 tingkat SMA dari Kementerian Pendidikan dan Kebudayaan, sedangkan mata pelajaran agama Islam sebagai ciri khas. Agar diperoleh hasil yang maksimal, implementasi kurikulum ini dibutuhkan kegiatan-kegiatan penguatan pembelajaran. Kegiatan ini dilaksanakan diluar waktu kegiatan pembelajaran di madrasah. Penguatan Materi Umum antara lain: (1) Club Sains Mapel (Matematika, Fisika, Kimia, Biologi, Ekonomi, Geografi/Geosain; (2) Pembinaan Khusus Mapel; (3) Pengembangan Diri Siswa: Pramuka, Robotik, KTI. Penguatan 
Materi Agama antara lain : Baca Tulis Qur'an, Latihan Dakwah, Tahfidhul qur'an, Tahfidhul Hadist.

Memperhatikan berbagai kebutuhan dalam membimbing siswa terkait dengan peningkatan prestasi mata pelajaran, maka MAN IC Batam menyelenggarakan program Kegiatan Pembinaan Khusus Mata Pelajaran. Tujuan kegiatan Program Pembinaan Khusus Mata Pelajaran secara umum bertujuan untuk memberikan pelayanan yang optimal dalam memenuhi kebutuhan siswa dalam pencapaian prestasi yang tinggi. Kegiatan ini dilaksanakan oleh pendidik sebagai instruktur dan tenaga kependidikan sebagai panitia yang ditetapkan selanjutnya dengan Surat Keputusan Kepala MAN lnsan Cendekia Batam.

\section{Program Kegiatan Pembinaan Mata Pelajaran}

Jenis Program ini antara lain Tutorial Individual, Kelas Adaptasi, dan Kelas Malam. Tutorial individual adalah kegiatan pembelajaran di luar jam kerja yang bertujuan untuk: (1) Meningkatkan daya serap siswa yang belum mencapai ketuntasan selanjutnya disebut Tutorial Individual Klinik; (2) Memberikan pengayaan bagi siswa pandai dan memiliki minat lebih pada mata pelajaran tertentu yang selanjutnya disebut Tutorial Individual Pengayaan. Kegiatan ini berbentuk bimbingan individual atau kelompok kecil (maksimal 4 orang) berdasarkan level ketuntasan dalam penyerapan materi pelajaran dan Pemenuhan minat akan pengayaan materi pelajaran. Peserta kegiatan ini adalah siswa yang tidak tuntas. Kegiatan dilakukan pada hari Sabtu pukul 07.00-10.00 (memilih waktu sesuai perjanjian). Bagi guru yang tinggal di asrama, kegiatan dapat dilaksanakan pada setiap malam hari, pukul 20.00-22.00, sesuai perjanjian dengan siswanya.

Kelas Adaptasi. Kelas adaptasi adalah kegiatan pembelajaran di luar jam kerja bagi siswa yang tidak bisa mengikuti pembelajaran regular di kelas karena mengikuti berbagai kegiatan lomba atau pelatnas persiapan kegiatan internasional dan juga bagi siswa yang sakit. Bentuk kegiatan ini adalah bimbingan individual atau kelompok kecil untuk mengejar ketertinggalan materi pelajaran yang tidak bisa mereka ikuti. Peserta kegiatan ini adalah siswa yang meninggalkan pelajaran reguler di kelas karena mengikuti berbagai kegiatan lomba atau pelatnas persiapan kegiatan internasional (OSK, OSP, OSN, KSM, OIS, dll) dan siswa yang sakit. Kegiatan adaptasi terdiri dari Pembelajaran teori, Mengerjakan soal-soal latihan pendalaman, dan Tes untuk mengetahui daya serap. Kegiatan ini dilakukan pada hari Sabtu pukul 07.00-12.00 (memilih waktu sesuai perjanjian). Bagi guru yang tinggal di asrama, kegiatan dapat dilaksanakan pada setiap malam hari, pukul 20.00-22.00, sesuai perjanjian dengan siswanya.

Kelas Malam. Kelas malam adalah kegiatan pembelajaran pada malam hari yang diadakan untuk keperluan persiapan ulangan akhir semester (UAS), ujian praktik kelas XII, ujian sekolah (US), Try Out, ujian akhir madrasah berstandar nasional (UAMBN) dan ujian nasional (UN). Bentuk kegiatan ini adalah bimbingan kelompok belajar berdasarkan pengelompokan yang dibentuk siswa sendiri. Peserta kegiatan adalah seluruh siswa. Kegiatan malam terdiri dari Pembelajaran teori dan mengerjakan soal-soal latihan pendalaman dan pembahasannya. Kegiatan malam ini dilaksanakan beberapa pekan menjelang pelaksanaan UAS, Ujian Praktik kelas XII, Try out, US, UAMBN dan UN, pada malam (pukul 20.00-22.00).

\section{Program ekstrakurikuler}

MAN IC Batam memiliki seperangkat kegiatan ekstrakurikuler yang mampu menampung semua kemampuan, minat, dan bakat siswa. Keragaman ekstrakurikuler akan membuat siswa dapat mengembangkan berbagai kemampuannya di berbagai bidang secara optimal. Ekstrakurikuler adalah suatu kegiatan yang direncanakan secara sistematis, bertahap, dan berjenjang yang ditujukan bagi siswa untuk mencapai perkembangan potensi diri secara optimal. Kegiatan ekstrakurikuler ini dilaksanakan secara rutin dan merupakan pembiasaan yang terprogram, berkesinambungan, tersusun secara periodik, dan merupakan wahana bagi siswa untuk mengembangkan kreativitas sesuai dengan bakat dan minatnya. 
Melalui kegiatan ekstrakurikuler siswa dapat membentuk kepribadian yang takwa terhadap Tuhan Yang Maha Esa, bersikap jujur dan sportif, serta mampu mengenali kelebihan dan kekurangan pada dirinya, memiliki motivasi, penuh semangat, gigih, dan pantang menyerah untuk meraih cita-cita. Mampu berkompetisi (bersaing) secara sehat untuk menjadi yang terbaik, memiliki gaya hidup penuh disiplin, taat pada aturan, hukum dan norma yang ada dalam masyarakat, di sisi lain mampu menghormati dan menghargai orang lain. Kegiatan ekstrakurikuler juga diharapkan dapat memberikan kesempatan yang lebih besar kepada siswa untuk mengembangkan kreativitas, meningkatkan kompetensi, dan tampil menunjukkan performance melalui suatu karya. Kegiatan ekstrakurikuler MAN IC Batam antara lain: Palang Merah Remaja (PMR), PASKIBRAKA, Seni Suara, Seni Musik, Seni Tari, Marawis/Nasyid, Seni Lukis, dan Multimedia/IT.

\section{Layanan Pembinaan di Asrama}

Layanan pembinaan peserta didik diasrama meliputi layanan pendidikan agama Islam; penguatan implementasi nilai-nilai keislaman yang terbuka, moderat, dan toleran serta berwawasan keindonesiaan dan penguatan keterampilan hidup bermasyarakat. Programprogram tersebut antara lain: Kegiatan Siraman Rohani, Kegiatan sosial kemasyarakatan, dan kegiatan pengembangan akhlakul karimah pada siswa-siswi MAN IC Batam.

\section{Program Pengembangan Bahasa Asing}

Salah satu keterampilan penting yang harus dimiliki oleh anak Indonesia agar dapat bersaing dalam dunia global adalah kemahiran dalam berbahasa asing. Untuk mencapai hal itu, MAN IC Batam mengadakan program pengembangan dan peningkatan bahasa asing tersebut, antara lain adalah bahasa Arab, bahasa Inggris, dan bahasa Jepang. Program ini meliputi pemberlakuan kurikulum, penerapan pendekatan komunikatif dalam pembelajaran bahasa, dan penyelenggaraan berbagai macam program pendukung lainnya yaitu Program Jangka Pendek (Kosa kata pagi, Gerakan Bahasa, Muhasabah, Pengembangan Diri, Hafalan kosa kata, Pendalaman bahasa, dll), Program Jangka Menegah (Lomba Bahasa,
Bahasa Ceria, Demonstrasi Bahasa, dll), dan jangka panjang (Kampung Arab untuk bahasa Arab, Lomba baca berita, Rihlah, dll).

\section{Program Pembiasaan MAN IC Batam}

Program ini terdiri dari berbagai kegiatan seperti: Sholat Dhuha, Sholat Tarawih, Sholat Berjamaah, Tadarus, dan Qiyamul Lail. Selain itu ada program keasramaan seperti MTQ (Syarhil, Tilawah dan Fahmil), Keputrian, Olahraga (Sepakbola, Futsal, Tenis meja, Bulu Tangkis, takraw, golf, dan Volly Ball), Silat, karate, taekwondo, dan Pendampingan Siswa Belajar Malam Hari.

\section{Pengembangan Life Skill}

Kepala Madrasah, guru, dan siswa mengembangkan kecakapan sosial dengan cara antara lain: (1) Berjabat tangan dan menyampaikan salam pada saat datang dan saat pulang sekolah, (2) Mengembangkan sikap menghargai pendapat ketika berdiskusi dalam kerja kelompok. Guru harus mampu mengembangkan kemampuan personal siswa dengan kegiatan pemecahan masalah yang kontekstual dan realistis, serta membangun kepercayaan diri siswa, (3) Warga Madrasah berusaha menggunakan bahasa Inggris dengan baik pada hari yang telah disepakati, (4) MAN Insan Cendekia Kota Batam, sesuai dengan kemampuan, kondisi, dan sumber daya yang dimiliki mengembangkan kecakapan hidup melalui keterampilan Penelitian dan Pembelajaran bahasa Jepang, dan (5) Setiap guru dalam proses pembelajaran harus dapat menciptakan suasana yang menyenangkan dan menantang kreativitas siswa, bertutur kata sesuai dengan norma yang berlaku, dan mampu menarik perhatian dan memberikan motivasi sebelum PBM berlangsung dengan yel-yel, nyanyian, cerita kontekstual dan aktual, dan yang lainnya.

\section{Jaringan kerjasama}

MAN IC Batam memiliki jaringan kerjasama yang baik dengan berbagai instansi, terutama instansi yang berhubungan dengan pendidikan dan pengembangan kompetensi siswa seperti Baznas Kota dan Propinsi, perusahaan swasta, Pusat Kesehatan Masyarakat (Puskesmas), Kepolisian (Polsek), Walikota (24 walikota se-Sumatera menanam 
pohon di MAN IC), tokoh-tokoh masyarakat, dan lainnya. Dengan adanya kerjasama dengan berbagai instansi akan mempermudah siswa untuk menerapkan sekaligus memahami berbagai sektor kehidupan.

\section{Evaluasi Produk}

Evaluasi produk adalah evaluasi yang bertujuan untuk mengukur, menginterpretasikan dan menilai pencapaian program (Stufflebeam \& Shienfield, 1985). Evaluasi produk merupakan penilaian yang dilakukan untuk melihat ketercapaian/keberhasilan suatu program dalam mencapai tujuan yang telah ditetapkan sebelumnya.

Sekolah unggul harus menghasilkan lulusan yang unggul. Keunggulan lulusan tidak hanya ditentukan oleh nilai ujian yang tinggi. Indikasi lulusan yang unggul ini baru dapat diketahui setelah yang bersangkutan memasuki dunia kerja dan terlibat aktif dalam kehidupan bermasyarakat. Kemampuan lulusan yang dihasilkan dirasa unggul, bila mereka telah mampu mengembangkan potensi intelektual, potensi emosional, dan potensi spiritualnya dimana mereka berada.

MAN IC Kota Batam baru pertama kali meluluskan siswanya pada tahun ini. Nilai Ujian Nasional siswa cukup memuaskan. Untuk tingkat Madrasah Aliyah baik negeri maupun swasta, MAN IC Batam menduduki peringkat pertama di Kepulauan Riau. Untuk tingkat SMA umum, MAN IC Batam mendapat urutan keempat nilai UN tertinggi untuk jurusan IPS, dan 10 besar untuk jurusan IPA.

Beberapa siswa juga diterima di PTN melalui jalur khusus. Data sementara, ada 7 siswa diterima di PTN melalui jalur khusus. Untuk jalur reguler, MAN IC belum mendapatkan data berapa siswa yang melanjutkan dan diterima di Perguruan Tinggi favorit.

\section{PENUTUP}

Penyelenggaraan MAN IC Batam secara umum telah berjalan sesuai dengan Pedoman Penyelenggaraan MAN Insan Cendikia. Proses rekruitmen siswa dan tenaga pendidik dan kependidikan berjalan sesuai dengan prosedur yang ditetapkan. Namun masih ada permasalahan khususnya pada keberadaan tenaga pendidik. Status guru yang diterima MAN IC adalah guru tetap bukan PNS. Ketika ada rekruitmen guru PNS, mereka diperbolehkan untuk mengikuti tes CPNS dan jika diterima mereka rata-rata tidak ditempatkan di MAN IC. Pemerintah harus melakukan rekruitmen lagi untuk memenuhi kebutuhan guru. Seringnya berganti guru dikhawatirkan akan berdampak pada peserta didik.

Sarana prasarana yang menunjang proses belajar mengajar secara minimal juga sudah terpenuhi. Namun untuk asrama guru masih jauh dari terpenuhi. Baru ada 4 unit asrama di MAN IC Batam. Idealnya setiap guru mendapatkan fasilitas asrama karena mengajar di madrasah berasrama dimana kegiatan juga dilakukan mulai dini hari sampai malam hari. Output yang dihasilkan MAN IC Batam sudah baik, menjadi madrasah terbaik dan banyak prestasi yang sudah diraih dalam tiga tahun baik prestasi akademik maupun non akademik.

Dari kesimpulan penelitian ini merekomendasikan: (1) MAN IC Kota Batam perlu melakukan evaluasi terhadap menurunnya minat masyarakat. Pemerintah perlu memberikan dukungan penuh terhadap penyelenggaraan MAN IC Kota Batam dengan meningkatkan standar sarana prasarana belajar dan fasilitas pendukung seperti asrama guru, (2) Pemerintah harus tegas membuat aturan terkait dengan status guru MAN IC. Alternatif lain, guru yang lolos dalam rekruitmen MAN IC berstatus PNS.

\section{UCAPAN TERIMAKASIH}

Terima kasih kepada Kepala Puslitbang Pendidikan Agama dan Keagamaan Badan Litbang dan Diklat yang telah memberi kesempatan kepada penulis untuk meneliti, Kepala dan Wakil Kepala MAN IC Kota Batam, guru dan Kepala Tata Usaha MAN IC Kota Batam yang turut membantu memberikan data dan informasi, juga kepada Redaktur Edukasi atas termuatnya tulisan ini. Semoga tulisan ini memberikan wawasan dalam pendidikan agama di Indonesia.

\section{DAFTAR PUSTAKA}

Agama, T. K. (2019) Statistik Pendidikan Islam Tahun Pelajaran 2019/2020 (Statstcs of 
Islamic Education school year 2019/2020). Jakarta.

Agustanico Dwi Muryadi (2017) 'Model Evaluasi Program Dalam Penelitian Evaluasi',

http://ejournal.utp.ac.id/index.php/JIP/ar ticle/view/538/522, 1(1), pp. 1-10. doi: 10.1037/0022-3514.51.6.1173.

Arikunto, S. (2010) Dasar-Dasar Evaluasi Pendidikan. Jakarta: Bumi Aksara.

Darmadji, A. (2010) 'Evaluasi Program Man Model Sebagai Upaya Peningkatan Mutu', Millah, IX(2), pp. 269-286. Available at: https://journal.uii.ac.id/Millah/article/vie w/5220/4658.

Evi, S. (2019) 'Evaluasi Program Pendidikan Terkemuka', EDUKASI: Jurnal Penelitian Pendidikan Agama dan Keagamaan, 17(2).

Harahap, E. . (2018) 'Manajemen Madrasah Berprestasi, Mandiri, Islami dan Berdaya Saing Global', Al Aslah, 2. Available at: StaimaarifJambi.ac.id.

Hayadin (2019) 'Orientasi Pilihan Studi dan Profesi Siswa MAN IC Serpong', EDUKASI: Jurnal Penelitian Pendidikan Agama dan Keagamaan, 17(1).

Indriani, F. and Satrianawati (2018) 'Evaluasi Penyelenggaraan Pendidikan Inklusi Berbasis Nilai-Nilai Pancasila Di Sd', Jurnal Penelitian Pendidikan, 35(2), pp. 143-154. Available at: https://journal.unnes.ac.id/nju/index.php/ JPP/article/view/15426/pdf.

Jeffrey Hill, E. (2008) EVALUATION MODELS Viewpoints on Education and Human Services Evaluation. 2nd edn. Edited by G. F. Madaus, C. Hill, and D. L. Stufflebeam.

doi: 10.1080/13668800802172576.

Lazwardi, D. (2017) 'Implementasi Evaluasi Program Pendidikan Di Tingkat Sekolah Dasar Dan Menengah', Kependidikan Islam, 7(2), pp. 67-79. Available at: http://ejournal.radenintan.ac.id/index.php /idaroh.

Maimun, M. (2016) 'Evaluasi Program Kelas
Unggulan di Madrasah Ibtidaiyah Negeri Punia Mataram', eL-HIKMAH: Jurnal Kajian dan Penelitian Pendidikan Islam, 10(2), pp. 143-156. doi: 10.20414/elhikmah.v10i2.221.

Muhaimin (2019) Manajemen Kepala Madrasah Dalam Sistem Penjaminan Mutu Madarsah (Studi Kasus di MAN IC Pekalongan). IAIN Salatiga.

Muhammad Murtadlo (2018) Dinamika Sejarah Madrasah di Asia Tenggara. Edited by R. Cecep Romli. Jakarta: Pesagirimandiri Perkasa.

Munawiroh, M. (2013) 'Evaluasi Penyelenggaran Madrasah Tsanawiyah Satu Atap (MTS-SA) Sabilul Muttaqien Pamekasan Jawa Timur', EDUKASI: Jurnal Penelitian Pendidikan Agama dan Keagamaan, 11(3). Available at: https://jurnaledukasikemenag.org/index.p hp/edukasi/article/view/420/359 (Accessed: 27 August 2018).

Munthe, A. P. (2015) 'Pentingya Evaluasi Program Di Institusi Pendidikan: Sebuah Pengantar, Pengertian, Tujuan dan Manfaat', Scholaria: Jurnal Pendidikan dan Kebudayaan, 5(2), p. 1. doi: 10.24246/j.scholaria.2015.v5.i2.p1-14.

Murtadlo, M. (2017a) Reorientasi Manajemen Madrasah. Jakarta: Pustaka Cendekia muda.

Murtadlo, M. (2017b) Strategi Pembiayaan Pendidikan di Madrasah. Pertama. Jakarta: Pustaka Cendekiamuda.

Muzayanah (2011) Evaluasi Program Pendidikan. Jakarta: Teknologi Pendidikan UNJ.

Najamuddin (2020) 'Effective School Management At MAN IC Gorontalo. Lentera Pendidikan', 23(1).

Nurhalimah, S. (2019) Manajemen Prestasi Siswa MAN IC Kota Kendari. IAIN Kendari.

Nurudin (2017) Madrasah dan Otonomi Daerah; Analisis Kebijakan Pendidikan. Edited by J. Musfah. Jakarta: Pustaka Cendekiamuda. 
Rosyada, D. (2013) Paradigma Pendidikan Demokratis, Sebuah Model Pelibatan Masyarakat dalam Penyelenggaraan Pendidikan. Jakarta: Prenandamedia Group.

Rosyada, D. (2017) Madrasah dan Profesionalisme Guru Dalam Arus Dinamika Pendidikan Islam di Era Otonomi Daerah. pertama. Edited by Murodi, Z. Muttaqin, and L. R. Fikri. Jakarta: Kencana.

Rusman (2011) Model Model Pembelajaran; Mengembangkan Profesionalisme Guru. ke 2. Jakarta: Rajagrafindo Persada.

Subhan, A. (2012) Lembaga Pendidikan Islam Indonesia Abad ke-20; Pergumulan antara Modernisasi dan Identitas. Jakarta: Kencana Prenada Media Grup.

Sukardi (2014) Evaluasi Program Pendidikan dan Pelatihan. Jakarta: Bumi Aksara.

Sukarno, M. (2014) 'Mengembangkan Madrasah Aliyah Negeri Insan Cendikia Untuk Menjawab Tantangan Modernisasi, Demokratisasi dan Globalisasi’.
Taufik, O. A. (2014) 'Determinasi Madrasah Efektif', Jurnal Administrasi Pendidikan UPI, 21(2), pp. 38-50. doi: 10.17509/jap.v21i2.6674.

Wirawan (2011) Evaluasi: Teori, Model, Standar, Aplikasi dan Profesi. Jakarta: Rajagrafindo Persada.

Wirawan (2017) Evaluasi Kinerja Sumber Daya Manusia (Teori, Aplikasi, dan Penelitian). Jakarta: Salemba Empat.

Yarbrough, D. B. (2010) 'Joint Committee on Standards for Educational Evaluation: The Program Standards: A Guide for Evaluators and Evaluation Users', in. California: Sage Publication.

Zainuddin (2016) Evaluasi Program Penyelenggaraan Madrasah Aliyah Negeri di Aceh Timur. Januari-Juni. Available at: https://media.neliti.com/media/publicatio ns/155859-ID-none.pdf (Accessed: 31 August 2018). 